\title{
CANONICAL CORRELATION ANALYSIS BETWEEN SUPPLY CHAIN QUALITY MANAGEMENT AND COMPETITIVE ADVANTAGES
}

\author{
Ahmad JAFARNEJAD CHAGHOOSHI, Mahsa SOLTANI-NESHAN*, \\ Mohsen MORADI-MOGHADAM
}

University of Tehran, Faculty of Management, Tehran, Iran

*e-mail: M.soltani20@ut.ac.ir

\begin{abstract}
Competitive environment of today's organizations, more than ever, is extensive, and the major concern for managers is to preserve and promote the sustainable competitive advantage. Companies have an obligation to improve their product quality and have extensive and close cooperation with other companies involved in the supply chain of products. Supply chain quality management (SCQM) is a systematic approach to improve the performance that integrates supply chain partners and uses the opportunity in the best way, establish linkages between upstream and downstream flows, and investigate on creating value and satisfaction of intermediaries and final customers. Furthermore, achieving competitive advantages enables an organization to create a remarkable position in market and differentiate itself from competitors. This paper aims to understand the relationships between SCQM and competitive advantage. Sixty-eight experts of 25 companies in Sahami Alyaf (SA) supply chain has been participated in this research. The research method used for this article is descriptive correlation. To assess the relationships between the criteria, canonical correlation analysis was used. The result shows that the SCQM and competitive advantages have a meaningful relationship. It also shows that most important variable in the linear combination of SCQM and competitive advantages are "customer focus and quality," respectively.
\end{abstract}

Keywords: supply chain quality management, competitive advantage, canonical correlation analysis.

\section{Introduction}

As competition moves beyond a single firm into the supply chain, focus is shifting from management of internal practices alone. Instead, quality managers must integrate their firms' practices with those of customers and suppliers. In the other hand, competition in the 1990s increased and markets became global, so it causes the new challenges: getting a product and service to the right place at the right time at the lowest cost.

Organizations start to understand that it is not enough to improve efficiencies within an organization but whole members in supply chain should make competitive (Zang et al.2013, Flynn and Flynn, 2005; Robinson and Malhotra, 2005). Findings of researchers indicate that supply chains have the opportunity to competing in a global market to achieve competitive advantages (Kim and Mokhashi, 2011). Meanwhile, the attention to supply chain has been extended and quality concepts has been added to the literature; the importance of quali- ty management makes researchers to focus more on quality management issues within the internal and external supply chain contexts (Crumbly,2015, Zang, 2013, Fish, 2011, Safari and Mohebi-Manesh, 2011). Supply chain quality management (SCQM) is the interdisciplinary field that links quality management (QM) to supply chain management (SCM). $\mathrm{Su}$ and $\mathrm{Li}$ (2011) presented a brief and comprehensive description: "SCQM is the effective integration of supply chain's internal QM activities."

As global markets evolve, supply chain managers are faced with many new challenges, as traditional approaches to managing supply chains will be ineffective. The integration of QM principles helps manager to broaden the perspective of SCM from its traditional narrow focus on the strategic importance of SCM and achieve competitive advantage (Wong and Karina, 2009, Flyn and Flyn, 2005).

Accordingly, in this paper, we attempt to explore how SCQM and competitive advantage related to each other. The next section will review the related literature. The third part states the conceptual 
model. In part four, we describe our research method. Finding follows on part five and final section contains the conclusions and further recommendations.

\section{Background}

Although there are many definitions of quality, however, the best definition may be observed at the study of Evan and Lindsey (2002). Quality means to exceed customer expectations. QM is an interdisciplinary task of industries and organizations. Its purpose is to control complex processes in dynamic environments. This means that the QM helps the decisionmaking process at all levels of the organization, both at the micro- and macro-level (Yeung, 2008). In today's economy, the competition is not among businesses but among supply chains. SCQM is an approach that seeks to integrate suppliers, manufacturers, distributors, and retailers, so that the product is produced in a right way and distributed in the right place, at right time, and with minimal cost and provides customer satisfaction (Simchi-Levi et al., 2008). Supply chain members need to learn to integrate with each other and grow and do the functional roles in the supply chain level continuously and smoothly. This thinking led to the development of SCQM. SCQM is a systematic approach to improve the performance that integrates supply chain partners and uses the opportunity in the best way, establish linkages between upstream and downstream flows, and investigate on creating value and satisfaction of intermediaries and final customers (Foster, 2008; Robinson and Malhotra, 2005). The main processes of the supply chain are product design, production, delivery, supporting, and supplier relationships with customer. To succeed in today's world, managers need to integrate their goals with dynamic and global economy and think about final consumers, and this is the unique thought that is followed by QM and total quality management at the ideal level (Fish, 2011). Stiller et al. (2014) studied the QM in different parts of the supply chain such as supply chain design, demand planning, scheduling procedures and procurement, inventory management and control, and supply chain planning and control. QM plays an important role in many processes of the supply chain design such as supplier identification, selection of suitable locations for production, supply chain demand planning, and taking the right decisions about operations that have been mentioned in the literature (Brauner et al., 2013; Fish, 2011; Schmitt and Beaujean, 2010; Monczka et al., 2009). Also the role of QM is obvious in procedures planning and supply chain inventory control. In studies, analyzes of $\mathrm{ABC} / \mathrm{XYZ}$ that have pursued the sourcing policies and have considered timely delivery are noted and also the quality of inventory control is emphasized (Benestin, 2011; Murphy, 2010; Lee et al., 2009). Also supply chain and customer relationship management has been studied from the perspective of QM. In this discussion, customer is not only the final customer, but with a view of the process, each member of the supply chain is a customer for another member and win-win relationships should have been established between partners and move toward the goals of the supply chain (Fish, 2011; Foster and Ogden, 2008; Flynn and Flynn, 2005).

For almost two decades, researchers have focused on identifying factors influencing the SCQM. By reviewing the studies, indexes and constituent dimensions of SCQM are stated as follows (Safari and Mohebbi Manesh, 2011):

- Customer Focus: customer-oriented or focusing on the customer emphasizes the mechanisms and infrastructures for communication with the customer, managers also need to know the needs of customers and the results of their satisfaction (Azar, 2010, Kuei et al. 2008; Kaynak and Hartley, 2008).

- Supplier Quality Management: Accordingly, supplier must be chosen based on the specific criteria, and comprehensive system should exist for evaluating and ranking them (Fish, 2011, Azar, 2010; Kaynak and Hartley, 2007).

- Quality Leadership: This item points the managers' commitment and support. Quality leadership focuses on the efforts of senior executives to what extent they can implement the unit quality policy in the supply chain (Azar, 2010, Chang, 2009; Kuei et al., 2008; Robinson and Malhotra, 2005). 
- Supply Chain Quality Strategies: Accordingly, there is a need to exist alignment between any organization's strategies and the other members of the supply chain, and strategies have been developed and reviewed with the cooperation of other members of the chain (Azar, 2010; Chang, 2009; Kuei et al., 2008).

- Process Approach: Accordingly, process approach should be considered at all steps of the supply chain and all steps of the organization (Azar, 2010; Lee et al., 2009).

- Supply Chain Information Systems: This item refers to the use of systems and technologies in the field of supply chain information and communication and information systems' capability of documenting and reporting regularly and timely (Kuei et al., 2008; Feldmann and Müller, 2003).

- Human Resource Development: Accordingly, there is need to emphasize to form teams to solve the supply chain quality problems and infrastructure of QM in supply chain level (Azar, 2010; Chang, 2009; Kuei et al., 2008).

From the perspective of researchers, organizations will be able to create synergy with SCQM and simultaneously increase the supply chain performance and the quality of final products to customers. This practice will lead the supply chain to the competitive advantage.

As mentioned earlier, today, competition is among supply chains; from the perspective of researchers, competitive advantage is the features and capabilities that enable an organization to maintain or improve its competitive position. The organization provides this situation by value creation for customers, reduces costs, and provides better service to distinguish its performance of the other competitors (Sukati et al., 2012; Thatte, 2007). All members of the supply chain are integrated together, and all this process causes that supply chain distinct from others and in fact makes it close to gain competitive advantage. Several researchers have examined the relationship between supply chain and competitive advantage and have provided satisfactory results (Crumbly, 2015; Singh et al., 2014; Sukati et al., 2012; Thatte, 2007; Lee et al., 2009).
As already mentioned, competitive advantage comprises capabilities that allow an organization to differentiate itself from its competitors; the empirical literature identifies the elements of competitive advantages in five factors: price/cost, quality, delivery dependability ( $\mathrm{Li}$ et al.; Davis et al, 2004; Tracy et al., 1999, Vickery et al., 1999), product innovation (Li et al., 2006; Koufteros et al., 1997; Kessler and Chakrabart, 1996), and time to market (Li et al., 2006; Rondeau et al., 2000; Handfield and Pannesi 1995, Zhang, 2001). Accordingly, we present our conceptual model and methodology in next part.

\section{Proposed method}

This conceptual model is composed of two types of variables: SCQM and competitive advantage as shown in Fig. 1.

The method we choose for our research is stronger than correlation analysis and regression analysis. Canonical correlation analysis (CCA) is the most common method of multivariate analysis that aims to determine the linear relationship between the multidimensional variables. The advantage of this approach is interpreting the relationship between the two variables, and it is a tool to reduce the size of the computational data. CCA also has some advantages in comparison to the multivariate regression analysis. While multivariate regression analysis calculates in the conditions in which only one dependent variable exists, CCA exceed a step further of multivariate regression analysis by adopting several dependent variables. The advantages of this method compared to the ordinary correlation analysis are that canonical method is dependent on the coordinate system in which it is defined. The method follows the coordinate system that has optimal level of correlation (Keshin and Yasser, 2007; LeClere, 2006; Nash and Chaloud, 2002).

Accordingly, to examine the relationship between SCQM and competitive advantage, CCA method is used.

The next part shows the result of our test with CCA method to explore the relationship between SCQM and competitive advantage. 


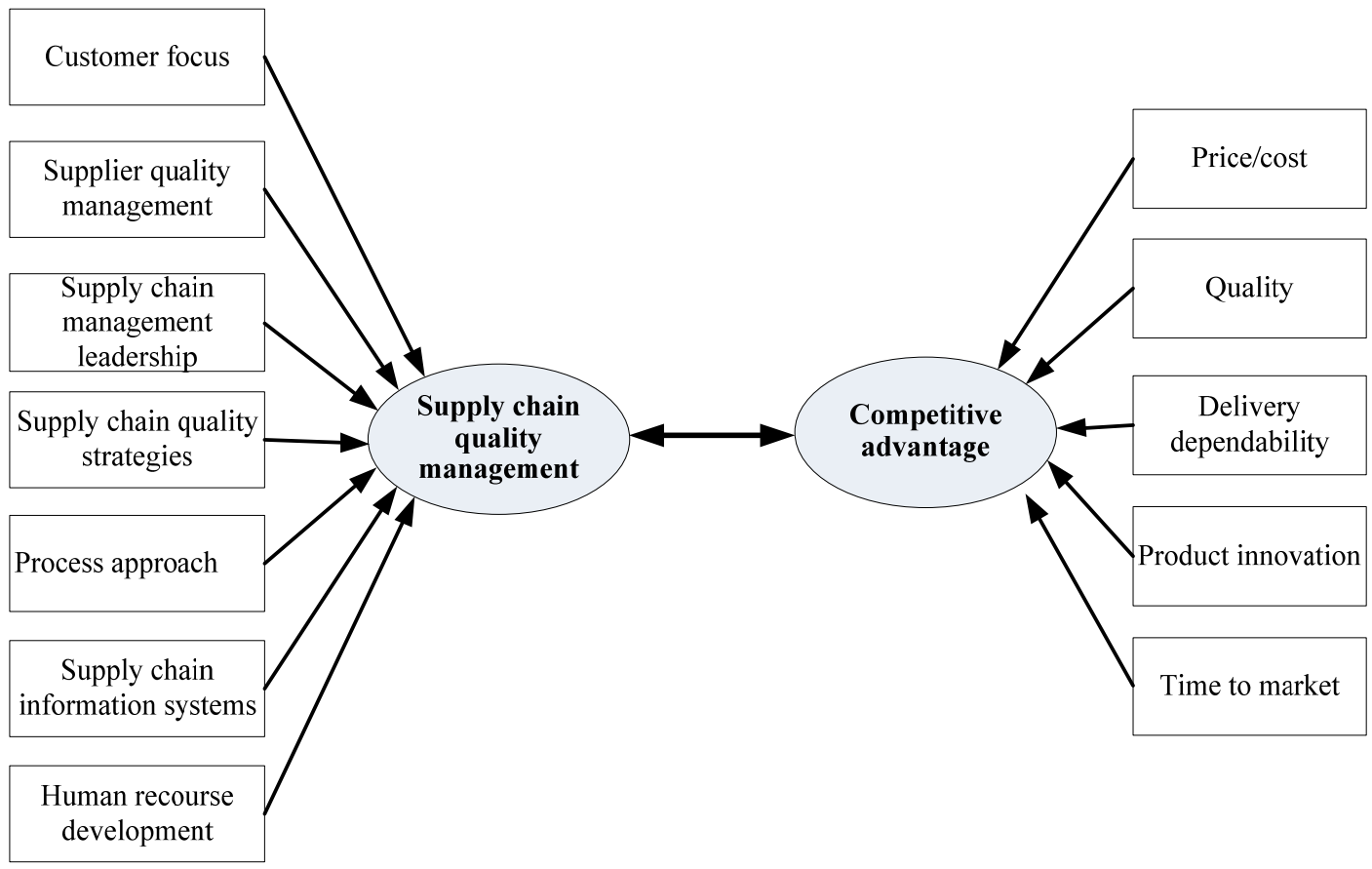

Figure 1. Research conceptual model

\section{$4 \quad$ Numerical example}

The population of the study consists of experts of 25 companies participated in Sahami Alyaf (SA) supply chain. These companies are responsible for raw materials in Sahami Alyaf Company, and their managers and experts have been chosen as statistical population and their comments were used as corporate data.Owing to the limited statistical population, for determination of sample size, some managers and experts of each of the 25 companies participated in SA supply chain are selected, and questionnaire was distributed among them. So, for each company, three or four of the questionnaires was provided to managers and experts in the field of supply chain and 96 questionnaires were distributed among the company's supply chain Managers totally.

Among 25 companies, two companies did not respond to the questionnaire, and the of 96 questionnaires distributed, 68 questionnaires were returned with a return rate of approximately $71 \%$ that is a relatively high rate of return. From this data, the data for the 23 companies were extracted. So that managers' ideas at each company (on an average 2.9 per company) were combined and corporate data about the research variables were determined. Ques- tionnaire were extracted by using $\mathrm{Li}$ et al. (2006) and Kaynak and Hartley (2008) methods.

Reliability of questionnaire was assessed by Cronbach's alpha and that Cronbach's alpha values of all variables and their dimensions were greater than 7.0.

Following results were obtained by using "Statistica" software.

Table 1 shows the output results of Statistica software. The table shows the variance values of SCQM and competitive advantage. As follows from the table, the presence of seven variables on the left and fived variables to the right, we're going to have five canonical variables (Table 1).

Canonical correlation expressed in the row above Table 1 shows the correlation coefficient of the first and the biggest canonical correlation that is equal to $89 \%$. Chi square and P-Value in the lower row shows the approved model. As the value of $\mathrm{P}$ is 0.01 and this amount is less than 0.05 , so the results are meaningful. The first level states that the canonicals roots can cover $100 \%$ of competitive advantage variance and more than $84 \%$ of SCQM variance. 
Table 1. CCA summary

\begin{tabular}{|c|c|c|}
\hline & & $\begin{array}{r}\text { Canonical R: 0.89, } \\
\mathrm{Chi}^{2}(35)=57, \mathrm{p}=0.01 \\
\end{array}$ \\
\hline $\mathbf{N}=\mathbf{2 3}$ & Supply Chain quality Management & Competitive advantage \\
\hline Number of variables & 7 & 5 \\
\hline Variance extracted & $84.64 \%$ & $100 \%$ \\
\hline Total redundancy & $58.33 \%$ & $58.86 \%$ \\
\hline \multicolumn{3}{|l|}{ Variables } \\
\hline 1 & Customer focus & Price/cost \\
\hline 2 & Supplier quality management & Quality \\
\hline 3 & Supply chain management leadership & Delivery dependability \\
\hline 4 & Supply chain quality strategies & Product innovation \\
\hline 5 & Process approach & Time to market \\
\hline 6 & Supply chain information systems & \\
\hline 7 & Human recourse development & \\
\hline
\end{tabular}

Table 2. The results Chi-square

\begin{tabular}{|c|c|c|c|c|c|c|}
\hline $\begin{array}{c}\text { Root } \\
\text { Removed }\end{array}$ & Canonical R & Canonical R $^{2}$ & Chi-square & df & P & $\begin{array}{c}\text { Lambda } \\
\text { Prime }\end{array}$ \\
\hline 1 & 0.899447 & 0.809060 & 57.21526 & 35 & 0.010347 & 0.024939 \\
\hline 2 & 0.850712 & 0.723711 & 31.55047 & 24 & 0.138662 & 0.130613 \\
\hline 3 & 0.676362 & 0.457465 & 11.61270 & 15 & 0.708058 & 0.472742 \\
\hline 4 & 0.295286 & 0.087194 & 2.13440 & 8 & 0.976607 & 0.871357 \\
\hline 5 & 0.213093 & 0.045408 & 0.72031 & 3 & 0.868416 & 0.954592 \\
\hline
\end{tabular}

The numbers in second row show that the SCQM could predict $58.3 \%$ of the variance of the competitive advantages and the competitive advantages could predict $58.86 \%$ of the variance of the SCQM.

In Table 2, the canonical correlation coefficients are shown. The second factor is the square of the correlation coefficients that is equal to the amount of eigenvalues. The P-value in the fifth column shows that if the value is above 0.05 , the canonical variables cannot be analyzed. In this analysis, only the first canonical variable can be analyzed.
Table 3 indicates the results of correlation relationship between left and right variables.

According to Table 3, the result shows that all of the subcriteria in SCQM and competitive advantages have a positive relation to each other. The average correlation between variables is 0.521 .

Therefore, $31 \%$ of subcriteria have the strong relationship with each other (more than 0.6).

In addition, the result indicates that the third subcriteria of SCQM (supply chain quality strategies) have the most meaningful relation to production innovation. 
Table 3. Correlation between variables

\begin{tabular}{|l|l|l|l|c|c|}
\hline & Price/cost & Quality & $\begin{array}{c}\text { Delivery } \\
\text { dependability }\end{array}$ & $\begin{array}{c}\text { Product } \\
\text { innovation }\end{array}$ & $\begin{array}{c}\text { Time } \\
\text { market }\end{array}$ \\
\hline Customer focus & 0.337771 & 0.544395 & 0.506738 & 0.392786 & 0.19845 \\
\hline Supplier quality management & 0.350460 & 0.462365 & 0.629974 & 0.500286 & 0.35676 \\
\hline $\begin{array}{l}\text { Supply chain management } \\
\text { leadership }\end{array}$ & 0.422008 & 0.389944 & 0.701408 & 0.486554 & .537234 \\
\hline Supply chain quality strategies & 0.461604 & 0.756677 & 0.752092 & 0.583981 & 0.25985 \\
\hline Process approach & 0.548473 & 0.688090 & 0.659407 & 0.583740 & 0.15204 \\
\hline Supply chain information systems & 0.333018 & 0.708139 & 0.749269 & 0.584666 & 0.27458 \\
\hline Human recourse development & 0.655876 & 0.596418 & 0.619850 & 0.647577 & 0.50910 \\
\hline
\end{tabular}

Table 4. The comparison between the most and the least relationship between criteria

\begin{tabular}{|c|c|c|c|}
\hline & Sub-criteria & $\begin{array}{c}\text { The most meaningful } \\
\text { relation }\end{array}$ & $\begin{array}{c}\text { The least meaningful } \\
\text { relation }\end{array}$ \\
\hline \multirow{7}{*}{ SCQM } & Customer focus & Quality & Time to market \\
\hline & $\begin{array}{l}\text { Supplier quality } \\
\text { management }\end{array}$ & Dependable delivery & Price $/$ cost \\
\hline & $\begin{array}{l}\text { Supply chain } \\
\text { management leadership }\end{array}$ & Dependable delivery & Quality \\
\hline & $\begin{array}{l}\text { Supply chain quality } \\
\text { strategies }\end{array}$ & Quality & Time to market \\
\hline & Process approach & Quality & Time to market \\
\hline & $\begin{array}{l}\text { Supply chain information } \\
\text { systems }\end{array}$ & Dependable delivery & Time to market \\
\hline & $\begin{array}{l}\text { Human recourse } \\
\text { development }\end{array}$ & Product innovation & Time to market \\
\hline \multirow{5}{*}{$\begin{array}{l}\text { Competitive } \\
\text { advantages }\end{array}$} & Price/cost & $\begin{array}{l}\text { Human resource } \\
\text { development }\end{array}$ & $\begin{array}{l}\text { Supply chain information } \\
\text { system }\end{array}$ \\
\hline & Quality & $\begin{array}{l}\text { Supply chain quality } \\
\text { strategies }\end{array}$ & SCM leadership \\
\hline & Dependable delivery & Customer focus & SC quality strategies \\
\hline & Product innovation & $\begin{array}{l}\text { Human resource } \\
\text { development }\end{array}$ & Customer focus \\
\hline & Time to market & SCM leadership & Process approach \\
\hline
\end{tabular}


The least relationship is for process approach and price.

Table 4 shows the most and the least correlation for each subcriteria.

Regarding to Table 4, the last subcriteria of competitive advantages (time to market) has the least relationship is with subcriteria of SCQM. Therefore, it seems for this item that SCQM subcriteria were not the suitable.

In Table 5, canonical weights of the left variables (supply chain quality management) and canonical weights of the right variables for root 1 (competitive advantage) are shown.
Canonical weights represents the importance and the magnitude of each main variables in the linear combination (or canonical variable) of total variables.

Given that the most important variable is the first canonical variable, focus solely on the analysis of this column. Accordingly, the most important sub criterion in the linear combination of SCQM (or canonical variable) is "supplier quality management". Also, the main sub criterion in the linear combination of competitive advantage is "quality".

Accordingly, the most important variable in the linear combination of SCQM (or canonical variable) is "customer focus".

Also, the main variable in the linear combination of competitive advantage is "quality".

Table 5. The canonical weight for sub-criteria of SCQM and competitive advantages (Root 1$)$

\begin{tabular}{|c|c|c|}
\hline Criteria & Sub-Criteria & Canonical Weight \\
\hline \multirow{7}{*}{ SCQM } & Customer focus & 0.039 \\
\hline & Supplier quality management & 0.184 \\
\hline & Supply chain management leadership & -0.470 \\
\hline & Supply chain quality strategies & -0.214 \\
\hline & Process approach & -0.152 \\
\hline & Supply chain information systems & 0.096 \\
\hline & Human recourse development & -0.594 \\
\hline \multirow{5}{*}{$\begin{array}{l}\text { Competitive } \\
\text { Advantages }\end{array}$} & Price/cost & -0.43 \\
\hline & Quality & 0.140 \\
\hline & Dependable delivery & -0.481 \\
\hline & Production innovation & -0.274 \\
\hline & Time to market & -0.291 \\
\hline
\end{tabular}

\section{Concluding remarks}

SCQM has become an essential prerequisite for staying competitive in the global market and enhancing the competitive advantages (Crumbly, 2015). In the past decade, companies have begun to recog- nize the need for continual quality improvement and meeting the needs of customers. Additionally, they make notice of the essential of competing quickly and efficiently in ever-changing global markets. As a result, SCM has been seen as a philosophy by which firms can operate interorganizationally 
and merge strategic with upstream and downstream flows that leads to excellence of business. Traditional quality programs focusing on approaches need to integrate with supply chain perspective that helps managers to meet the customer requirement and achieve competitive advantages. Accordingly the concept of SCQM has received increasing attention from academicians and professional recently. In this paper, we use the canonical correlation analysis to assess the relationship between SCQM and competitive advantages in SA supply chain. The 68 experts of 25 companies in SA supply chain has been participated in this research. The result shows that there is a meaningful relationship between SCQM and competitive advantages and they could cover around $50 \%$ variance of each other. It also indicates that the subcriteria of SCQM is mostly related to dependable delivery and quality. In addition, there is no meaningful relationship between SCQM subcriteria and time to market. Finally, the findings claim that the most important variable in the linear combination of SCQM and a competitive advantage is "customer focus" and "quality" respectively. One of the interesting results was the relationship between subcriteria of SCQM and competitive advantages that give the researcher this opportunity to study on this field more.

\section{Acknowledgments}

We would like to thank all colleagues in developing this research. We significantly benefited from thoughts and idea of MeysamMaleki. We also acknowledges Fundaçãopara a Ciência e Tecnologia da Faculdade de Ciências e Tecnologia Project MIT$\mathrm{Pt} / \mathrm{EDAM}-\mathrm{IASC} / 0022 / 2008$, it is supported by a $\mathrm{PhD}$ fellowship from this foundation.

\section{$7 \quad$ Reference}

[1] Azar A., Kahnali R.A., Taghavi A. (2010) Relationship between Supply Chain Quality Management Practices and their Effects on Organisational Performance. Singapore Management Review, 1(32), 45-68.

[2] Barney J. (1991) - Firm resources and sustained competitive advantage, Journal of Management, 17(1). 99-120.
[3] Benstin M.S., Benston D.P., Haraburda S.S. (2011) - Using Value Engineering to Reduce Life Cycle Costs. Defense AT\&L, 40(1), 31-34.

[4] Brauner P., Runge S., Groten M., Schuh G., Ziefle M., (2013) - Human Factors in Supply Chain Management - Decision making in complex logistic scenarios, in Proceedings of the 15th HCI International 2013, Part III, LNCS 8018, 2013. 423-432.

[5] Chang G. (2009) - Total quality management in supply chain. International Business Research; 2 (2): 82-85.

[6] Crumbly J. (2015) - The Moderating Impact of Total Quality Management on Supply Chain Management: Implication of Competitive Advantage. Revolution in Marketing: Market Driving Changes. Springer International Publishing. 149-154.

[7] Davis E.W., Spekman R.E. (2004) - Extended Enterprise: Gaining competitive advantage through collaborative supply chains, PrenticeHall.

[8] Evans J., Lindsay W. (2002) - The Management and Control of Quality, Fifth Edition. SouthWestern College Publishing, Cincinnati, Ohio.

[9] Feldmann M., Müller S. (2003) - An incentive scheme for true information providing in supply chains. Omega,31(2):63-73.

[10] Fish L.A. (2011) - Supply Chain Management Pathways for Research and Practice. Edited by Dilek Önkal and Emel Aktas, InTech, chapter 3, Supply Chain Quality Management, ISBN 978953-307-294-4.

[11] Flynn B.B., Flynn E.J. (2005) - Synergies between supply chain management and quality management: emerging implications. International Journal of Production Research, 43(16),3421-3436.

[12] Foster S.T. Jr., Ogden J. (2008) - On differences in how operations and supply chain managers approach quality management. International Journal of Production Research, 46(24),69456961.

[13] Foster S.T. Jr. (2008) - Towards an understanding of Supply Chain Quality Management. Journal of Operations Management, 26, 461-467. 
[14] Handfield R.B., Pannesi R.T. (1995) - Antecedents of lead-time competitiveness in make-toorder manufacturing firms. International Journal of Production Research,33(2):511-537.

[15] Kaynak H., Hartley H.J.L. (2008) - A replication and extension of quality management into the supply chain. Journal of Operations Management;26 (4): 468- 89.

[16] Keskin S., Yasar F. (2007) - Use of canonical correlation analysis for determination of relationships among several traits in eggplant (solanum melongena l.) under salt stress. Pakistan Journal of Botany, 39(5), 1547-1552.

[17] Kessler E., Chakrabarti A. (1996) - Innovation speed: a conceptual mode of context, antecedents, and outcomes. The Academy of Management Review, 21(4):1143-91.

[18] Kim S.L., Mokhashi K.H. (2011) - Supply Chain Management - Pathways for Research and Practice. Edited by Dilek Önkal and Emel Aktas, InTech, chapter10, Production and Delivery Policies for Improved Supply Chain Performance, ISBN 978-953-307-294-4.

[19] Koufteros X.A., Vonderembse M.A., Doll W.J. (1997) - Competitive capabilities: measurement and relationships. Proceedings Decision Science Institute, 1067-68.

[20] Kuei C., Madu C.N, Lin C. (2008) - Implementing supply chain quality management. Total Quality Management; 19 (11), 1127-1141.

[21] LeClere J.M. (2006) - Bankruptcy studies and ad hoc variable selection: A canonical correlation analysis. Review of Accounting and Finance, 5(4), 410-422.

[22] Lee K., Wei C., Lee H. (2009) - Reducing exposed copper on annual rings in a PCB factory through implementation of a Six Sigma project. Total Quality Management \& Business Excellence, 20( 8), 863-876.

[23] Li S., Ragu-Nathan B., Ragu-Nathan T.S., and Rao S. Subba (2006) - The Impact of Supply Chain Management Practices on Competitive Advantage and Organizational Performance, Omega, 34(2), 107-124.

[24] Management.18(5):509-29.

[25] Monczka R.M., Handfield R.B., Giunipero L.C., Patterson, J.L. (2009) - Purchasing and Supply
Chain Management, Fourth Edition. SouthWestern Cengage Learning, Mason, $\mathrm{OH}$.

[26] Murphy W.H. (2010) - Bull's-eye. Quality Progress. 43(6),22-29.

[27] Nash M.S., Chaloud D.J. (2002) - Multivariate analyses (canonical correlation and partial least square (PLS)) to model and assess the association of landscape metrics to surface water chemical and biological properties using savannah river basin data. U.S. Environmental Protection Agency Las Vegas, Nevada, USA.

[28] Robinson C.J., Malhotra M.K. (2005) - Defining the concept of Supply Chain Quality Management and its relevant to academic and industrial practice. International Journal of Production Economics, 96,315-337.

[29] Rondeau P.J., Vonderembse M.A., Ragu-Nathan T.S. (2000) - Exploring work system practices for time-based manufacturers: their impact on competitive advantage. Journal of Operations.

[30] Safari H., Mohebimanesh O. (2011) - A conceptual model of supply chain quality management and evaluation of the situation in Iran khodro, Tehran: Tehran University, Faculty of Management (in Persian).

[31] Schmitt R., Beaujean P. (2010) - Self-optimizing production - Implications for quality management. International Journal of Total Quality Management, \& Excellence, 3, 231-242.

[32] Sila I., Ebrahimpour M., Birkholz C. (2006) Quality in supply chains: an empirical analysis. Supply Chain Management: An International Journal; 11(6): 491-502.

[33] Simchi Levi D., Kaminsky P. (2000) - Designing and Managing the Supply chain, New York, McGraw Hill.

[34] Singh R., Sandhu H.S., Metri B.A., Kaur R. (2014) - Supply Chain Management Practices, Competitive Advantage and Organizational Performance: A Confirmatory Factor Model. International Journal of Information Systems and Supply Chain Management (IJISSCM), 6(4). 2246.

[35] Stiller S., Falk B., Philipsen R., Brauner P., Schmitt R., Ziefle M. (2014) - A Game-based Approach to Understand Human Factors in Supply Chains and Quality Management, Proce- 
dia of 2nd International Conference on RampUp Management 20, 67-73.

[36] Su Q., Liu Q. (2011) - Supply Chain Management - Pathways for Research and Practice. Edited by Dilek Önkal and Emel Aktas, InTech , chapter 5, Supply Chain Quality Management by Contract Design, ISBN 978-953-307-294-4.

[37] Sukati I., Hamid A.B.A., Baharun R., Alifiah M. N., Anuar M.A. (2012) - Competitive advantage through supply chain responsiveness and supply chain integration. International Journal of Business and Commerce (IJBC), 1(7).

[38] Tan K.C., Lyman S.B., Wisner J.D. (2002) Supply chain management: a strategic perspective, International Journal of Operations and Production Management. 22(6), 614-31.

[39] Thatte A.A. (2007) - Competitive advantage of a Firm Through Supply Chain Responsiveness and Supply Chain Management Practices, Published PhD Dissertation. University of Toledo.

[40] Tracey M., Vonderembse M.A., Lim J.S. (1999) - Manufacturing technology and strategy formulation: keys to enhancing competitiveness and improving performance. Journal of Operations Management. 17(4):411-28.

[41] Vickery S., Calantone R., Droge C. - Supply chain flexibility: an empirical study. Journal of Supply Chain Management.35(3):16-24.

[42] Wong C.Y., Karia N. (2009) - Explaining the competitive advantage of logistics service providers: A resource-based view approach, Int. J. Production Economics Article in Press.

[43] Yeung A.C.L. (2008) - Strategic supply management, quality initiatives, and organizational performance, Journal of Operations Management, 26, 490-502.

[44] Zeng J., Phan C.A, Matsui Y. (2013) - Supply chain quality management practices and performance: An empirical study, Operations Management Research, 6,19-31.

[45] Zhang Q.Y. (2001) -Technology infusion enabled value chain flexibility: a learning and capability-based perspective. Doctoral dissertation, University of Toledo, Toledo, $\mathrm{OH}$. 